\title{
Proximate Chemical Composition of Dried Shrimp and Tilapia Waste Bioflocs Produced by Two Drying Methods
}

\author{
Tarq Binalshikh-Abubkr ${ }^{1,2}$, Marlia M. Hanafiah ${ }^{1,3, *}$ and Simon Kumar Das ${ }^{1,4}$ \\ 1 Department of Earth Sciences and Environment, Faculty of Science and Technology, \\ Universiti Kebangsaan Malaysia, Bangi 43600, Malaysia; p93366@siswa.ukm.edu.my (T.B.-A.); \\ simon@ukm.edu.my (S.K.D.) \\ 2 Department of Food Science and Technology, Faculty of Environmental Science and Marine Biology, \\ Hadhramout University, Mukalla P.O. Box 50512, Yemen \\ 3 Centre for Tropical Climate Change System, Institute of Climate Change, Universiti Kebangsaan Malaysia, \\ Bangi 43600, Malaysia \\ 4 Marine Ecosystem Research Center (EKOMAR), Faculty of Science and Technology, \\ Universiti Kebangsaan Malaysia, Bangi 43600, Malaysia \\ * Correspondence: mhmarlia@ukm.edu.my
}

Citation: Binalshikh-Abubkr, T.; Hanafiah, M.M.; Das, S.K. Proximate Chemical Composition of Dried Shrimp and Tilapia Waste Bioflocs Produced by Two Drying Methods. J. Mar. Sci. Eng. 2021, 9, 193.

https://doi.org/10.3390/jmse9020193

Academic Editor: Gulnihal Ozbay

Received: 28 January 2021

Accepted: 9 February 2021

Published: 12 February 2021

Publisher's Note: MDPI stays neutral with regard to jurisdictional claims in published maps and institutional affiliations.

Copyright: (c) 2021 by the authors. Licensee MDPI, Basel, Switzerland. This article is an open access article distributed under the terms and conditions of the Creative Commons Attribution (CC BY) license (https:/ / creativecommons.org/licenses/by/ $4.0 /)$.

\begin{abstract}
The effects of two waste sources, red hybrid tilapia (Oreochromis sp.) and whiteleg shrimp (Litopenaeus vannamei), and two drying methods (freeze-drying and oven-drying) on the proximate chemical composition of bioflocs were investigated. In total, four kinds of experimentally treated bioflocs were compared to identify the best waste source and drying method to produce biofloc of an acceptable nutrient value: freeze-dried shrimp biofloc (FDSBF), oven-dried shrimp biofloc (ODSBF), freeze-dried tilapia biofloc (FDTBF), and oven-dried tilapia biofloc (ODTBF). The protein, lipid, ash, fiber, total nitrogen free extract (NFE), and energy contents of the dried bioflocs ranged from 12.12 to $24.09 \mathrm{~g} / 100 \mathrm{~g}$, 0.35 to $0.92 \mathrm{~g} / 100 \mathrm{~g}$, 42.45 to $61.01 \mathrm{~g} / 100 \mathrm{~g}, 7.43$ to $17.11 \mathrm{~g} / 100 \mathrm{~g}$, 16.45 to $18.59 \mathrm{~g} / 100 \mathrm{~g}$, and 0.99 to $1.94 \mathrm{Kcal} \mathrm{g}^{-1}$, respectively. Statistically, there were significant differences within the means of the two biofloc sources in terms of their proximate compositions $(p<0.05)$. The average values between the drying methods for protein, lipid, total NFE, and energy were also significantly different, while no significant differences $(p>0.05)$ were recorded for ash and fiber. Amino acids (AAs) were higher in FDTBF, followed by ODTBF. The mineral profiles showed that phosphorous, potassium, manganese, selenium, and copper were higher in the tilapia waste bioflocs, while calcium, zinc, iron, copper, chromium, and cobalt were higher in the shrimp waste bioflocs. Although the statistical analysis showed that the shrimp waste bioflocs had higher levels of lipid, fiber, total NFE, and minerals, the tilapia waste bioflocs contained higher levels of potential AAs, energy, and protein, which are regarded as expensive ingredients in aquaculture feeding. This study indicates that biofloc derived from tilapia waste can be regarded as a more suitable source of biofloc meal (in terms of protein, ash, energy, and AAs) than biofloc derived from shrimp waste. Our findings also suggest that freeze-drying is a more effective drying method for drying biofloc, as it efficiently maintains nutritional quality.
\end{abstract}

Keywords: biofloc; freeze-drying; oven-drying; whiteleg shrimp; red hybrid tilapia; proximate composition; amino acids; minerals

\section{Introduction}

In order to meet nutritional demands, global aquaculture production has been rapidly increasing in recent decades [1]. However, many negative effects have been associated with increasing aquaculture activities, such as the use of large quantities of water, the high cost of feed ingredients, especially fish meal and fish oil, and drainage of used aquaculture water, which is highly concentrated in toxic substances due to the high load of organic matter, nitrogen compounds, and phosphorus into the receiving water bodies [2-4]. For 
example, the water quality of receiving water body has been found to be affected by the physicochemical characteristics of catfish farm's effluent for several parameters such as nitrate and chemical oxygen demand (COD) that exceed the recommended raw water quality criteria [2]. In addition to the environmental impact, these substances also have major negative effects on human health [5-7]. Therefore, a sustainable aquaculture system is required to protect the environment, natural resources, and human health $[8,9]$.

Biofloc technology systems (BFTs) are currently considered an economical and environmentally sustainable approach for aquaculture systems [10,11]. BFTs provide a complementary source of nutrition that is useful for enhancing production by improving the growth performance and survival rates of aquatic organisms [12]. BFTs work on the basis of the conversion of waste to nutrients by adding a carbohydrate source (such as molasses) to maintain the carbon-to-nitrogen ratio $(\mathrm{C} / \mathrm{N})$ at a high level (10-20:1), which also catalyzes heterotrophic bacteria, thus generating energy from carbohydrates to produce proteins, whereby ammonia can be converted into microbial floc [8,13-18]. From this point of view, having biofloc in situ is of interest because biofloc not only provide aquaculture animals with nutrients and enhance production, but are also able to save up to $24 \%$ of the costs of commercial feed, thus reducing the overall costs of aqua feeding [4,19]. Not only can fresh biofloc be consumed in situ as live food by cultured animals, but dried biofloc may also be used as a protein source in diets [18,20-23].

Drying is one of the most important globally recognized procedures for food preservation [24]. There are various methods for drying, and although there are differences in terms of their principles, processing, applications, advantages, and disadvantages, all aim to reduce the moisture in food in order to preserve it [25]. For example, in the oven-drying method, the sample is heated under specified conditions, and the efficiency of drying is highly dependent on many factors, such as the type of oven, the conditions inside the oven, the drying time and temperature, the humidity percentage inside the sample, the thickness of the sample, particle size, surface area, etc. [26]. Another method, freeze-drying, is mainly used to prevent damage to heat-sensitive products, mostly of biological origin. The sample is frozen before vacuum freeze-drying, then water (in ice form) is removed by sublimation. Later, it is removed by desorption, and the product can thus be easily preserved [27].

Currently, the nutritional value of biofloc needs to be determined [28]. Dried biofloc bring higher profits for farmed species when used as a replacement for expensive ingredients, such as fishmeal, or if used as a supplement to commercial feed in aquatic feed manufacturing [18,29]. Moreover, biofloc is considered a good quality source of protein that can be used as a feed and contribute $50 \%$ of the protein requirements for tilapia (Oreochromis niloticus), and possibly for other fish species $[13,30]$. Biofloc consists of more than $30 \%$ crude protein, and about $2 \%$ of the meal is made up of lipids [31,32].

Factors such as the density and particle size of the biofloc, the carbon source that is supplied, the environmental conditions, water quality parameters, and food preferences of the animals have been found to affect the characteristics and nutritional composition of biofloc $([8,10,13,15-18,33-36]$. The biofloc source and the method of drying could also influence the nutritional composition, since various proximate compositions (the protein, lipid, ash, fiber, carbohydrate, and energy contents) have been observed in many previous studies using several methods (sunlight, air-drying, oven-drying, and freeze-drying) and different drying temperatures and times [18,22,36-43]. Nonetheless, the effects of different waste sources and drying methods on the nutrient composition of dried biofloc have yet to be explored.

This study aims to investigate and compare the effects of two waste sources of bioflocred hybrid tilapia and whiteleg shrimp-and two drying methods (oven-drying and freezedrying) on the proximate chemical composition of dried biofloc samples. The data obtained from this study will facilitate the identification of appropriate sources and drying methods to produce dried biofloc meal with a good nutrient value. 


\section{Materials and Methods}

\subsection{Raw Materials and Drying Methods}

Bioflocs were collected from six indoor adult red hybrid tilapia and whiteleg shrimp tanks at Sepang Today Aquaculture Center located in Selangor, Malaysia $\left(2^{\circ} 37^{\prime} 14.8^{\prime \prime} \mathrm{N}\right.$ $101^{\circ} 41^{\prime} 53.2^{\prime \prime} \mathrm{E}$ ), which were produced by daily addition of molasses as a carbon source, and the ratio of $\mathrm{C} / \mathrm{N}$ was maintained at 15:1 [44]. Biofloc volume was measured by sampling $1 \mathrm{~L}$ of water from each tank using Imhoff cones, and the flocs were allowed to settle at the bottom of the cone and were left for $15 \mathrm{~min}$ to obtain a stable biofloc volume [13]. When the volume of biofloc had reached $40 \mathrm{~mL} / \mathrm{L}$, the bioflocs were collected using different mesh sizes of plankton nets $(20 \mu \mathrm{m}, 30 \mu \mathrm{m}$, and $40 \mu \mathrm{m})$. The collected bioflocs were kept in plastic zipper storage bags and stored in a cold store box, then transported to the lab. The wet bioflocs were then divided into four portions: two portions were immediately frozen at $-80^{\circ} \mathrm{C}$ for $48 \mathrm{~h}$ and then transferred to a vacuum freeze-dryer (Alpha 1-2 LDplus, CHRIST, Osterode am Harz, Germany) for $72 \mathrm{~h}$ [18], and the other two portions were dried in a forced air circulation oven (Memmert UF110, Büchenbach, Germany) at $40{ }^{\circ} \mathrm{C}$ for $72 \mathrm{~h}$ [42]. The dried bioflocs were ground into fine particles $(<100 \mu \mathrm{m})$ and kept in airtight containers in a refrigerator (Toshiba, GR- H41ST, Bangkok, Thailand) at below $-18{ }^{\circ} \mathrm{C}$ for further analyses.

\subsection{Experimental Biofloc Treatments}

To examine the proximate chemical composition of bioflocs collected from red hybrid tilapia and whiteleg shrimp tanks using biofloc systems, the freeze-dried bioflocs were obtained using a freeze-drying method, while the oven-dried bioflocs were obtained using an oven-drying method. The dried bioflocs were then divided into four experimental biofloc treatment groups: freeze-dried shrimp biofloc (FDSBF), oven-dried shrimp biofloc (ODSBF), freeze-dried tilapia biofloc (FDTBF), and oven-dried tilapia biofloc (ODTBF).

\subsection{Proximate Composition Analyses}

The proximate composition of the bioflocs was analyzed according to Association of Official Analytical Chemists (A.O.A.C.) [45] and the following standard methods for animal feed analysis were used.

\subsubsection{Ash Measurement}

A porcelain crucible of known weight with $10 \mathrm{~g}$ of dry sample was used for ash analysis and was incinerated in a muffle furnace (Nabertherm, Germany) at $550{ }^{\circ} \mathrm{C}$ for $4 \mathrm{~h}$. The crucible was then removed from the muffle oven, cooled in a desiccator, and weighed. The analysis was done in triplicate, and the ash content was calculated according to the following formula:

$$
\text { Ash }(\%)=(\text { ash weight } / \text { sample weight }) \times 100
$$

\subsubsection{Crude Protein Measurement}

The crude protein content was determined by the Kjeldahl method, which measures the nitrogen $(\mathrm{N})$ content of a sample. The protein content was then calculated by assuming a ratio of protein to $\mathrm{N}$ for the specific food being analyzed $(\mathrm{N} \times 6.25)$ [46]. The Kjeldahl procedure is divided into three steps: digestion, distillation, and titration. Approximately $0.5 \pm 0.01 \mathrm{~g}$ of sample (in triplicate) was filled into digestion tubes, and $12 \mathrm{~mL}$ of sulfuric acid $\left(98 \% \mathrm{H}_{2} \mathrm{SO}_{4}, \mathrm{~N}\right.$-free) was added. In the digestion step, each mixture of sample and $\mathrm{H}_{2} \mathrm{SO}_{4}$ was heated in the presence of $3 \mathrm{~g}$ of catalyst $\left(7.0 \mathrm{~g} \mathrm{~K}_{2} \mathrm{SO}_{4}+0.8 \mathrm{~g} \mathrm{Cu}\right)$ at $420{ }^{\circ} \mathrm{C}$ for an hour. When the color of the samples changed to neon green, the tube rack with the covered digestion tubes was removed and placed in the cooling stand to allow the samples to cool for $15 \mathrm{~min}$ before starting the distillation step. In the distillation unit (Kjetlec ${ }^{\mathrm{TM}}$ 8200, Höganäs, Sweden), the manufacturer's standard operation procedure was followed to warm up the machine (Steam). After the distillation process, the distillate was titrated 
against $0.1 \mathrm{~N}$ of standardized $\mathrm{HCl}$ solution in the presence of methyl red methylene blue to the first colorimetric endpoint, where the solution changed to red color. The crude protein content was then calculated according to the AOAC methods [45].

\subsubsection{Crude Lipid Measurement}

The crude lipid percentage was determined using a fat extraction system (Soxtec $^{\mathrm{TM}}$ 2043, FOSS, Denmark). A $1.5 \mathrm{~g}$ sample (in triplicate) was used for the measuring and the crude lipid content was calculated according to the AOAC methods [45].

\subsubsection{Crude Fiber Measurement}

The crude fiber content was measured by a fiber analysis system (FiberCap ${ }^{\mathrm{TM}} 2022$, FOSS, Denmark). The crude fiber was determined via sequential extraction of the sample with $1.25 \%(w / v) \mathrm{H}_{2} \mathrm{SO}_{4}$ and $1.25 \%(w / v) \mathrm{NaOH}$ solutions under specific conditions (AOAC, 2016-method 962.09). The insoluble residue was collected by filtration, and the residue was dried, weighed, and ashed to correct for any mineral contamination of the fiber residue.

\subsubsection{Calculation of Total Nitrogen Free Extract}

The total nitrogen free extract (NFE) content in the bioflocs was measured as follows: NFE $(\%)$ in dry matter $=100-$ total ash $\%+$ crude protein $\%$ + crude lipid $\%$ + crude fiber \%] [37].

\subsubsection{Gross Energy Measurement}

A bomb calorimeter (Model Parr 6100, Moline, IL, USA) was used to calculate gross energy by combusting $1 \mathrm{~g}$ of sample in a chamber pressurized with pure oxygen and measuring the resulting heat via the increase in the temperature of the water surrounding the chamber.

\subsection{Amino Acid Profile}

An amino acid analysis (AAA) was performed using High Performance Liquid Chromatography (HPLC) (Waters 1525, San Diego, CA, USA) provided with a binary pump and a multi $\lambda$ fluorescence detector (Waters 2475, USA). An AccQ tag column $(3.9 \times 150 \mathrm{~mm})$ was used for deproteinization (the separation of AAs from proteins and polypeptides). The AAA was carried out using the $6 \mathrm{~N} \mathrm{HCl}$ hydrolysate method in two phases: acid hydrolysis and a derivatization process via chromatographic analysis. To hydrolyze the proteins, $5 \mathrm{~mL}$ of $6 \mathrm{~N} \mathrm{HCL}$ was added to the samples and hydrolyzed in an oven with a vacuum at $110^{\circ} \mathrm{C}$ for $24 \mathrm{~h}$. After hydrolysis, the tubes were cooled and the solution was filtered using a Spartan HPLC syringe filter, then distilled water was added at a 1:20 $v / v$ ratio. The HPLC procedure was carried out at $36^{\circ} \mathrm{C}$, and the mobile phase contained AccQ Tag Eluent A, AccQ Tag Eluent B, or a $60 \%$ acetonitrile gradient system, and the flow rate was $1 \mathrm{~mL} / \mathrm{min}$. The fluorescence detector was set at $250 \mathrm{~nm}$ for excitation and $395 \mathrm{~nm}$ for emission. The injecting volume was $10 \mu \mathrm{L}$ [47].

\subsection{Minerals Profile}

The quantitative analysis of the minerals was carried out using an inductively coupled plasma mass spectrophotometer (ICP-MS) (PerkinElmer SCIEX-ELAN 9000, Waltham, MA, USA). Before the analysis, the samples were prepared by adding $10 \mathrm{~mL}$ of de-ionized water, $7.5 \mathrm{~mL}$ of $\mathrm{HCl}$, and $2.5 \mathrm{~mL}$ of nitric acid ( $\mathrm{NOH} 65 \%$ ) to $1 \mathrm{~g}$ of sample (dry powder), then the solution was heated to $150^{\circ} \mathrm{C}$ for $2 \mathrm{~h}$. After cooling, the samples were filtered using $0.45-\mu$ Whatman ashless filter paper in $25-\mathrm{mL}$ volumetric flasks, and the flasks were made up to $25 \mathrm{~mL}$ with de-ionized water. The diluted solutions were poured into polyethylene bottles and kept at $4{ }^{\circ} \mathrm{C}$ until further analysis [48]. 


\subsection{Statistical Analysis}

Descriptive statistics (mean \pm standard error [SE]) were performed using IBM SPSS Statistic software, version 22. Data were tested for normality and homogeneity of the variances using Kolmogorov-Smirnov and Levene's tests. Differences in proximate composition, amino acids, and mineral values between sources of bioflocs (shrimp waste and tilapia waste) were analyzed using two independent sample $t$-tests. The same test was also used to determine the differences in proximate composition, amino acids, and mineral values between the methods of drying (freeze-drying and oven-drying). Significant differences among the means were taken at $p<0.05$.

\section{Results}

\subsection{Proximate Composition}

The proximate composition, such as crude protein, crude lipid, total ash, crude fiber, nitrogen free extract (NFE) ( $\mathrm{g} / 100 \mathrm{~g})$, and energy $\left(\mathrm{Kcal} \mathrm{g}^{-1}\right)$ of the four experimentally treated bioflocs (FDSBF, ODSBF, FDTBF, and ODTBF) are presented in Table 1.

Table 1. T-test results (multiple comparisons) of proximate composition of biofloc (g/100 g dry matter) from two waste sources (shrimp and tilapia) and two methods of drying (freeze-drying and oven-drying).

\begin{tabular}{ccccc}
\hline & FDSBF & ODSBF & FDTBF & ODTBF \\
\hline & & Proximate composition & $24.09 \pm 0.18^{\mathrm{c}}$ & $20.52 \pm 0.09^{\mathrm{d}}$ \\
Protein & $13.50 \pm 0.27^{\mathrm{a}}$ & $12.12 \pm 0.09^{\mathrm{b}}$ & $0.40 \pm 0.01^{\mathrm{c}}$ & $0.56 \pm 0.01^{\mathrm{d}}$ \\
Lipid & $0.35 \pm 0.01^{\mathrm{a}}$ & $0.92 \pm 0.01^{\mathrm{b}}$ & $42.45 \pm 0.29^{\mathrm{b}}$ & $44.63 \pm 0.29^{\mathrm{b}}$ \\
Ash & $61.01 \pm 0.29^{\mathrm{a}}$ & $60.63 \pm 0.29^{\mathrm{a}}$ & $16.61 \pm 0.29^{\mathrm{b}}$ & $17.11 \pm 0.29^{\mathrm{b}}$ \\
Fiber & $7.43 \pm 0.29^{\mathrm{a}}$ & $7.74 \pm 0.29^{\mathrm{a}}$ & $16.45 \pm 0.17^{\mathrm{c}}$ & $17.18 \pm 0.58^{\mathrm{d}}$ \\
Nitrogen free extract (NFE) & $17.72 \pm 0.25^{\mathrm{a}}$ & $18.59 \pm 0.10^{\mathrm{b}}$ & $1.94 \pm 0.06^{\mathrm{b}}$ & $1.11 \pm 0.06^{\mathrm{c}}$ \\
\hline Energy (Kcal g & (1) & $0.99 \pm 0.06^{\mathrm{a}}$ & $1.01 \pm 0.06^{\mathrm{a}, \mathrm{c}}$ & \\
\hline
\end{tabular}

Data are means $\pm \mathrm{SE}, n=3$. Treatments: freeze-dried shrimp biofloc (FDSBF), oven-dried shrimp biofloc (ODSBF), freeze-dried tilapia biofloc (FDTBF), and oven-dried tilapia biofloc (ODTBF). Means with different superscripts in rows are significantly different $(p<0.05)$.

The protein content $(\mathrm{g} / 100 \mathrm{~g})$ was higher in both freeze-dried and oven-dried bioflocs from the tilapia source $(24.09 \pm 0.18 \mathrm{~g} / 100 \mathrm{~g}$ and $20.52 \pm 0.09 \mathrm{~g} / 100 \mathrm{~g}$, respectively) than the shrimp source (freeze-dried: $13.50 \pm 0.27 \mathrm{~g} / 100 \mathrm{~g}$ and oven-dried: $12.12 \pm 0.09 \mathrm{~g} / 100 \mathrm{~g}$ ) (Table 1). The $t$-test showed significant differences in protein content $(p<0.05)$ among the four treatment groups, wherein the protein content of the FDTBF was significantly higher $(24.09 \pm 0.18 \mathrm{~g} / 100 \mathrm{~g}, p<0.05)$ when compared with results of the ODTBF $(20.52 \pm 0.09 \mathrm{~g} / 100 \mathrm{~g})$ and the FDSBF $(13.50 \pm 0.27 \mathrm{~g} / 100 \mathrm{~g})$. Whereas the protein content of the FDSBF was significantly higher $(p<0.05)$ than the ODSBF, which recorded the lowest protein content $12.12 \pm 0.09 \mathrm{~g} / 100 \mathrm{~g}$ (Table 1).

The shrimp-derived biofloc samples showed higher lipid content $(0.92 \pm 0.01 \mathrm{~g} / 100 \mathrm{~g}$, $p<0.05)$ using the oven-drying method when compared with the tilapia waste biofloc samples using the freeze-drying method $(0.40 \pm 0.01 \mathrm{~g} / 100 \mathrm{~g})$ and using the oven-drying method $(0.56 \pm 0.01 \mathrm{~g} / 100 \mathrm{~g})$. However, the lowest lipid value $(0.35 \pm 0.01 \mathrm{~g} / 100 \mathrm{~g}$, $p<0.05$ ) was recorded for the FDSBF (Table 1 ). The $t$-test also found significant differences among the four treatment groups in lipid content $(p<0.05)$ (Table 1$)$.

Ash contents were higher in freeze-dried and oven-dried bioflocs from the shrimp waste $61.01 \pm 0.29 \mathrm{~g} / 100 \mathrm{~g}$ and $60.63 \pm 0.29 \mathrm{~g} / 100 \mathrm{~g}$, respectively, while they were lower in freeze-dried and oven-dried bioflocs from the tilapia waste of $42.45 \pm 0.29 \mathrm{~g} / 100 \mathrm{~g}$ and $44.63 \pm 0.29 \mathrm{~g} / 100 \mathrm{~g}$, respectively. The FDSBF samples were significantly higher in ash content than the FDTBF samples $(p<0.05)$ (Table 1). Additionally, the ash content from the ODSBF samples was significantly higher $(p<0.05)$ than that from the ODTBF samples. No significant differences $(p>0.05)$ were found between the FDSBF and the ODSBF samples or between the FDTBF and the ODTBF samples in terms of ash content (Table 1). This implies that both sources of bioflocs (shrimp waste and tilapia waste) had a significant effect on ash content $(p<0.05)$ (Table 1$)$. 
Fiber content was higher in freeze-dried and oven-dried bioflocs sourced from tilapia waste $(16.61 \pm 0.29 \mathrm{~g} / 100 \mathrm{~g}$ and $17.11 \pm 0.29 \mathrm{~g} / 100 \mathrm{~g}$, respectively) compared with freeze-dried and oven-dried bioflocs sourced from shrimp waste $(7.43 \pm 0.29 \mathrm{~g} / 100 \mathrm{~g}$ and $7.74 \pm 0.29 \mathrm{~g} / 100 \mathrm{~g}$, respectively) (Table 1). Statistically, significant differences were found between the two sources of bioflocs (tilapia waste and shrimp waste) $(p<0.05)$, while no significant differences were found $(p>0.05)$ between the drying methods in terms of fiber content. This also shows that the source of biofloc had a significant effect on fiber content (Table 1).

NFE content was significantly higher $(p<0.05)$ in freeze-dried $(17.72 \pm 0.25 \mathrm{~g} / 100 \mathrm{~g})$ and oven-dried $(18.59 \pm 0.10 \mathrm{~g} / 100 \mathrm{~g})$ bioflocs from shrimp waste, while significantly lower $(p<0.05)$ in freeze-dried $(16.45 \pm 0.17 \mathrm{~g} / 100 \mathrm{~g})$ and oven-dried $(17.18 \pm 0.58 \mathrm{~g} / 100 \mathrm{~g})$ bioflocs from tilapia waste (Table 1 ). The $t$-test showed significant differences in NFE content $(p<0.05)$ among the four treatment groups, where the ODSBF samples were significantly higher when compared with the FDSBF samples and also the ODTBF samples, while the FDTBF samples recorded the lowest NFE $(p<0.05)$ content (Table 1$)$.

Moreover, energy levels were higher in freeze-dried and oven-dried bioflocs from tilapia waste $\left(1.94 \pm 0.06\right.$ and $1.11 \pm 0.06 \mathrm{Kcal} \mathrm{g}^{-1}$, respectively), while lower in freezedried and oven-dried bioflocs from shrimp waste $\left(0.99 \pm 0.06\right.$ and $1.01 \pm 0.06 \mathrm{Kcal} \mathrm{g}^{-1}$, respectively) (Table 1$)$. The FDTBF samples were significantly $(p<0.05)$ higher when compared with the ODTBF samples, and also the FDSBF samples in terms of energy content (Table 1).

In general, tilapia waste bioflocs showed higher $(p<0.05)$ contents of protein, fiber, and energy, while shrimp waste bioflocs showed higher $(p<0.05)$ lipid, ash, and NFE contents (Table 1). As a drying method, freeze-dried bioflocs showed higher $(p<0.05)$ protein and energy contents, while oven-dried bioflocs showed higher $(p<0.05)$ lipid and NFE contents (Table 1).

\subsection{Amino Acid Profile}

The $t$-test of the quantitative analyses of the amino acids (AAs) for the four experimentally derived bioflocs (FDSBF, ODSBF, FDTBF, and ODTBF) is shown in Table 2. The AA concentrations were expressed as $1 \mathrm{~g}$ of amino acid per $100 \mathrm{~g}$ dry matter of biofloc. Table 2 shows that the FDTBF samples recorded the highest values $(p<0.05)$ of both essential amino acids (EAAs) and non-essential amino acids (NEAAs) $(10.584 \mathrm{~g} / 100 \mathrm{~g}$ and $9.657 \mathrm{~g} / 100 \mathrm{~g}$, respectively), followed by the ODTBF samples $(8.888 \mathrm{~g} / 100 \mathrm{~g}$ and $8.493 \mathrm{~g} / 100 \mathrm{~g}$, respectively). The FDSBF and ODSBF samples recorded the lowest values in EAAs (5.583 g/100 $\mathrm{g}$ and $5.464 \mathrm{~g} / 100 \mathrm{~g}$, respectively) as well as NEAAs $(7.375 \mathrm{~g} / 100 \mathrm{~g}$ and $7.258 \mathrm{~g} / 100 \mathrm{~g}$, respectively) (Table 2).

For the EAAs, the values of arginine, histidine, isoleucine, leucine, lysine, methionine, phenylalanine, threonine, and valine were significantly higher $(p<0.05)$ in bioflocs derived from tilapia waste (FDTBF and ODTBF) when compared with bioflocs from shrimp waste (FDSBF and ODSBF). Furthermore, the $t$-test showed that there were significant differences between the two methods of drying for tilapia waste bioflocs $(p<0.05)$, while no significant differences were found between the two methods of drying for shrimp waste bioflocs in terms of EAAs $(p>0.05)$. For the NEAAs, the values of alanine, aspartic, glutamic, glycine, proline, serine, and tyrosine were also significantly higher $(p<0.05)$ in bioflocs from tilapia waste (FDTBF and ODTBF) compared with bioflocs from shrimp waste (FDSBF and ODSBF), while hydroxyproline was significantly higher $(p<0.05)$ in the ODSBF samples (Table 2). Significant differences were also found for all values of NEAAs between the two methods of drying for tilapia waste bioflocs $(p<0.05)$. In contrast, no significant differences were found $(p>0.05)$ in the values of alanine, glutamic, glycine, proline, and tyrosine between the two drying methods for shrimp waste bioflocs, however, the values of aspartic and serine were significantly different $(p<0.05)$ between the FDSBF and ODSBF samples (Table 2). 
Table 2. $T$-test results (multiple comparisons) of the amino acids of biofloc ( $\mathrm{g} / 100 \mathrm{~g}$ ) from two waste sources (shrimp and tilapia) and two methods of drying (freeze-drying and oven-drying).

\begin{tabular}{|c|c|c|c|c|}
\hline Amino Acids & FDSBF & ODSBF & FDTBF & ODTBF \\
\hline \multicolumn{5}{|c|}{ Essential amino acids (EAAs) } \\
\hline Arginine & $0.678 \pm 0.01^{\mathrm{a}}$ & $0.661 \pm 0.02^{\mathrm{a}}$ & $0.965 \pm 0.04^{b}$ & $0.836 \pm 0.02^{\mathrm{c}}$ \\
\hline Histidine & $0.261 \pm 0.02^{\mathrm{a}}$ & $0.229 \pm 0.02^{\mathrm{a}}$ & $2.170 \pm 0.03^{b}$ & $1.883 \pm 0.05^{\mathrm{c}}$ \\
\hline Isoleucine & $0.588 \pm 0.02^{\mathrm{a}}$ & $0.595 \pm 0.02^{\mathrm{a}}$ & $0.977 \pm 0.02^{b}$ & $0.837 \pm 0.02^{c}$ \\
\hline Leucine & $0.947 \pm 0.01^{\mathrm{a}}$ & $0.943 \pm 0.01^{\mathrm{a}}$ & $1.568 \pm 0.01^{b}$ & $1.316 \pm 0.01^{\mathrm{c}}$ \\
\hline Lysine & $0.656 \pm 0.01^{\mathrm{a}}$ & $0.603 \pm 0.01^{\mathrm{a}}$ & $0.991 \pm 0.01^{b}$ & $0.758 \pm 0.01^{\mathrm{c}}$ \\
\hline Methionine & $0.205 \pm 0.01^{\mathrm{a}}$ & $0.204 \pm 0.01^{\mathrm{a}}$ & $0.361 \pm 0.01^{b}$ & $0.316 \pm 0.01^{c}$ \\
\hline Phenylalanine & $0.634 \pm 0.01^{\mathrm{a}}$ & $0.662 \pm 0.02^{\mathrm{a}}$ & $1.085 \pm 0.02^{b}$ & $0.869 \pm 0.01^{\mathrm{c}}$ \\
\hline Threonine & $0.742 \pm 0.01^{\mathrm{a}}$ & $0.711 \pm 0.01^{\mathrm{a}}$ & $1.088 \pm 0.02^{b}$ & $0.943 \pm 0.01^{c}$ \\
\hline Valine & $0.872 \pm 0.02^{\mathrm{a}}$ & $0.856 \pm 0.02^{\mathrm{a}}$ & $1.379 \pm 0.02^{b}$ & $1.130 \pm 0.03^{c}$ \\
\hline \multicolumn{5}{|c|}{ Non-essential amino acids (NEAAs) } \\
\hline Alanine & $1.149 \pm 0.01^{\mathrm{a}}$ & $1.136 \pm 0.01^{\mathrm{a}}$ & $1.694 \pm 0.01^{b}$ & $1.387 \pm 0.01^{\mathrm{c}}$ \\
\hline Aspartic & $1.574 \pm 0.01^{\mathrm{a}}$ & $1.476 \pm 0.02^{b}$ & $2.251 \pm 0.04^{\mathrm{c}}$ & $1.876 \pm 0.03^{\mathrm{d}}$ \\
\hline Glutamic & $1.636 \pm 0.02^{\mathrm{a}}$ & $1.567 \pm 0.04^{\mathrm{a}}$ & $2.317 \pm 0.03^{b}$ & $1.934 \pm 0.04^{\mathrm{c}}$ \\
\hline Glycine & $1.051 \pm 0.01^{\mathrm{a}}$ & $1.009 \pm 0.02^{\mathrm{a}}$ & $0.275 \pm 0.01^{b}$ & $0.231 \pm 0.04^{\mathrm{c}}$ \\
\hline Hydroxyproline * & - & $0.220 \pm 0.01^{\mathrm{a}}$ & $0.092 \pm 0.01^{b}$ & $0.130 \pm 0.01^{\mathrm{c}}$ \\
\hline Proline * & $0.734 \pm 0.01^{\mathrm{a}}$ & $0.693 \pm 0.01^{\mathrm{a}}$ & $1.210 \pm 0.01^{b}$ & $1.385 \pm 0.01^{\mathrm{c}}$ \\
\hline Serine & $0.822 \pm 0.01^{\mathrm{a}}$ & $0.737 \pm 0.01^{b}$ & $1.164 \pm 0.01^{\mathrm{c}}$ & $0.999 \pm 0.01^{d}$ \\
\hline Tyrosine & $0.409 \pm 0.01^{\mathrm{a}}$ & $\begin{array}{c}0.420 \pm 0.01^{\mathrm{a}} \\
\text { Total }\end{array}$ & $0.654 \pm 0.01^{b}$ & $0.551 \pm 0.01^{\mathrm{c}}$ \\
\hline AAs & 12.958 & 12.722 & 20.241 & 17.381 \\
\hline EAAs & 5.583 & 5.464 & 10.584 & 8.888 \\
\hline NEAAs & 7.375 & 7.258 & 9.657 & 8.493 \\
\hline EAAs/AAs & $43.09 \%$ & $42.95 \%$ & $52.29 \%$ & $51.14 \%$ \\
\hline
\end{tabular}

${ }^{*}$ Conditional essential amino acids. Data are means \pm SE, $n=3$. Treatments: freeze-dried shrimp biofloc (FDSBF), oven-dried shrimp biofloc (ODSBF), freeze-dried tilapia biofloc (FDTBF), and oven-dried tilapia biofloc (ODTBF). Means with different superscripts in rows are significantly different $(p<0.05)$.

In general, the total AA content in the samples from the FDTBF and ODTBF of tilapia waste bioflocs was higher $(20.241 \mathrm{~g} / 100 \mathrm{~g}$ and $17.381 \mathrm{~g} / 100 \mathrm{~g}$, respectively) than the FDSBF and ODSBF samples (12.958 g/100 $\mathrm{g}$ and $12.722 \mathrm{~g} / 100 \mathrm{~g}$, respectively). The EAAs in the FDTBF and ODTBF samples made up $52 \%$ and $51 \%$, respectively, of the total AAs and made up $43 \%$ and $42 \%$ of the AAs in the FDSBF and ODSBF samples, respectively (Table 2).

\subsection{Minerals Profile}

The four mineral profiles of the experimentally derived bioflocs are shown in Table 3. Concentrations of essential major minerals: calcium (Ca), phosphorus (P), magnesium $(\mathrm{Mg})$, potassium $(\mathrm{K})$, and sodium $(\mathrm{Na})$, were expressed as mg per $\mathrm{g}$ dry matter of biofloc, while concentrations of essential trace minerals: manganese (Mn), zinc $(\mathrm{Zn})$, iron (Fe), selenium (Se), copper $(\mathrm{Cu})$, chromium $(\mathrm{Cr})$, and cobalt $(\mathrm{Co})$, were expressed as $\mathrm{mg}$ per $\mathrm{kg}$ dry matter of biofloc (Table 3).

Ca was present in the highest concentration among the major minerals $\left(69.74 \pm 2.02 \mathrm{mg} \mathrm{g}^{-1}\right)$, while $\mathrm{K}$ was at the lowest $\left(1.44 \pm 0.17 \mathrm{mg} \mathrm{g}^{-1}\right)$ for shrimp waste bioflocs (Table 3). In contrast, $\mathrm{Zn}$ was highest among the trace minerals $\left(337 \pm 0.04 \mathrm{mg} \mathrm{kg}^{-1}\right)$, while the lowest value of $0.5 \pm 0.01$ was recorded for Se, also in the shrimp waste bioflocs (Table 3). As presented in Table 3, significant differences were observed using a $t$-test for most of the major and trace minerals between the sources of bioflocs. Concentrations of $\mathrm{Ca}, \mathrm{Zn}$, $\mathrm{Fe}, \mathrm{Cu}, \mathrm{Cr}$, and $\mathrm{Co}$ were significantly higher $(p<0.05)$ in shrimp waste bioflocs, while concentrations of $\mathrm{P}, \mathrm{K}$, and Mn were significantly higher $(p<0.05)$ in tilapia waste bioflocs (Table 3). The $t$-test also showed significant differences $(p<0.05)$ between the methods of drying for tilapia waste bioflocs, while no significant differences $(p>0.05)$ were noted between the drying methods of shrimp waste bioflocs in terms of minerals (Table 3). Ca, $\mathrm{P}, \mathrm{Mn}, \mathrm{Zn}, \mathrm{Fe}, \mathrm{Cu}, \mathrm{Cr}$, and Co were significantly higher $(p<0.05)$ in the ODTBF samples 
$(44.70 \pm 1.10,12.68 \pm 0.46,260 \pm 0.02,232 \pm 0.02,187 \pm 0.12,17 \pm 0.03,6.3 \pm 0.06$, and $4 \pm 0.03$, respectively) when compared with the FDTBF samples $(21.85 \pm 0.52,3.22 \pm 0.35$, $53 \pm 0.01,25 \pm 0.02,135 \pm 0.06,3.7 \pm 0.03,4.5 \pm 0.06$, and $1.2 \pm 0.03$, respectively) (Table 3 ).

Table 3. $T$-test results (multiple comparisons) of mineral concentration of biofloc (in dry matter) from two waste sources (shrimp and tilapia) and two methods of drying (freeze-drying and oven drying).

\begin{tabular}{|c|c|c|c|c|}
\hline & FDSBF & ODSBF & FDTBF & ODTBF \\
\hline \multicolumn{5}{|c|}{ Major minerals $\left(\mathrm{mg} \mathrm{g}^{-1}\right)$} \\
\hline $\mathrm{Ca}$ & $66.03 \pm 1.39^{\mathrm{a}}$ & $69.74 \pm 2.02^{\mathrm{a}}$ & $21.85 \pm 0.52^{c}$ & $44.70 \pm 1.10^{\mathrm{b}}$ \\
\hline $\mathrm{P}$ & $4.81 \pm 0.46^{\mathrm{a}, \mathrm{c}}$ & $4.74 \pm 0.29^{a}$ & $3.22 \pm 0.35^{\mathrm{c}}$ & $12.68 \pm 0.46^{b}$ \\
\hline $\mathrm{Mg}$ & $17.58 \pm 0.92^{\mathrm{a}, \mathrm{b}}$ & $17.58 \pm 0.53^{\mathrm{a}, \mathrm{b}}$ & $17.58 \pm 0.40^{\mathrm{b}}$ & $17.58 \pm 2.02^{b}$ \\
\hline $\mathrm{K}$ & $1.44 \pm 0.017^{\mathrm{a}, \mathrm{b}}$ & $1.53 \pm 0.12^{\mathrm{a}}$ & $1.65 \pm 0.23^{b}$ & $2.132 \pm 0.08^{b}$ \\
\hline $\mathrm{Na}$ & $11.48 \pm 0.40^{\mathrm{a}, \mathrm{b}}$ & $11.48 \pm 0.87^{\mathrm{a}, \mathrm{b}}$ & $10.77 \pm 0.36^{\mathrm{b}}$ & $11.48 \pm 0.69^{b}$ \\
\hline \multicolumn{5}{|c|}{ Trace minerals $\left(\mathrm{mg} \mathrm{kg}^{-1}\right)$} \\
\hline $\mathrm{Mn}$ & $160 \pm 0.02^{\mathrm{a}}$ & $172 \pm 0.04^{\mathrm{a}}$ & $53.0 \pm 0.01^{b}$ & $264 \pm 0.02^{c}$ \\
\hline $\mathrm{Zn}$ & $337 \pm 0.04^{\mathrm{a}}$ & $277 \pm 0.05^{\mathrm{a}, \mathrm{b}}$ & $25.0 \pm 0.02^{c}$ & $232 \pm 0.02^{b}$ \\
\hline $\mathrm{Fe}$ & $264 \pm 0.35^{\mathrm{a}}$ & $235 \pm 0.63^{a, b}$ & $135 \pm 0.06^{\mathrm{c}}$ & $187 \pm 0.12^{b}$ \\
\hline Se & $0.80 \pm 0.02^{\mathrm{a}, \mathrm{b}}$ & $0.50 \pm 0.01^{\mathrm{a}, \mathrm{b}}$ & $0.60 \pm 0.01^{b}$ & $0.90 \pm 0.02^{b}$ \\
\hline $\mathrm{Cu}$ & $15.0 \pm 0.03^{\mathrm{a}}$ & $17.0 \pm 0.03^{\mathrm{a}, \mathrm{b}}$ & $3.70 \pm 0.03^{c}$ & $17.0 \pm 0.03^{b}$ \\
\hline $\mathrm{Cr}$ & $16.9 \pm 0.03^{a}$ & $15.4 \pm 0.03^{\mathrm{a}}$ & $4.50 \pm 0.06^{\mathrm{c}}$ & $6.30 \pm 0.06^{b}$ \\
\hline Co & $3.80 \pm 0.04^{a}$ & $4.20 \pm 0.07^{\mathrm{a}, \mathrm{b}}$ & $1.20 \pm 0.03^{c}$ & $4.00 \pm 0.03^{b}$ \\
\hline
\end{tabular}

Data are means \pm SE, $n=3$. Treatments: freeze-dried shrimp biofloc (FDSBF), oven-dried shrimp biofloc (ODSBF), freeze-dried tilapia biofloc (FDTBF), and oven-dried tilapia biofloc (ODTBF). Ca: Calcium; P: Phosphorus; Mg: Magnesium; K: Potassium; Na: Sodium; Mn: Manganese; Zn: Zinc; Fe: Iron; Se: Selenium; Cu: Copper; Cr: Chromium Co: Cobalt. Means with different superscripts in rows are significantly different $(p<0.05)$.

\section{Discussion}

The observations documented that tilapia waste bioflocs have better proximate and chemical compositions than shrimp waste bioflocs, and dried bioflocs from the freezedrying method have better proximate and chemical compositions than bioflocs from the oven-drying method. We observed that protein levels were significantly higher $(24.09 \mathrm{~g} / 100 \mathrm{~g},(p<0.05)$ in the FDTBF samples (Table 1$)$. Higher protein percentages (30-49 g/100 g) were recorded in bioflocs (by dry weight) by many researchers in previous studies [12,20,22,30,42,49-53]. Lower percentages of protein were documented by Himaja et al. [41] (16.61 g/100\%) and Durigon et al. [43] (17.39 g/100 g) in bioflocs collected from a tilapia waste source and dried by oven drying at $45^{\circ} \mathrm{C}$ and $55^{\circ} \mathrm{C}$ for $72 \mathrm{~h}$, respectively.

According to Tacon [54], most aquaculture species require a protein content of $20-50 \mathrm{~g} / 100 \mathrm{~g}$ in their diet. Although biofloc meet the nutritional standards for aquaculture feeding, it has to be noted that the protein from biofloc should only be considered as a supplement for dietary proteins [8]. Based on earlier studies, dietary supplementation with biofloc ranging from $4 \%$ to $50 \%$ can improve growth performance and enhance the immune system of cultured organisms $[18,21,36,37,39,42,55]$. Therefore, the protein contents of 20 and $24 \mathrm{~g} / 100 \mathrm{~g}$ recorded in the present study from the tilapia waste bioflocs, in addition to their superior protein content to shrimp waste bioflocs, suggest that this source be used for dietary protein supplementation in the formulation of fish diets.

As shown in Table 1 , the methods of drying also significantly $(p<0.05)$ affected the protein levels in the dried bioflocs. Freeze-dried bioflocs had higher protein content than oven-dried bioflocs from both shrimp and tilapia waste sources $(24.09 \pm 0.18$ and $13.50 \pm 0.27 \mathrm{~g} / 100 \mathrm{~g}$, respectively). A similar protein percentage $(24.30 \mathrm{~g} / 100 \mathrm{~g})$ was observed for the bioflocs produced individually in the three $1000 \mathrm{~L}$ indoor fiberglass reinforced plastic tanks [37] using a hot air oven-drying method at $45^{\circ} \mathrm{C}$. Furthermore, drying at room temperature or air-drying in a greenhouse also resulted in a protein percentage of $24 \mathrm{~g} / 100 \mathrm{~g}$ [55,56]. Lee et al. [18] used a freeze-dryer for biofloc meal collected from the sludge formed on the water surface in shrimp tanks, and $28.7 \mathrm{~g} / 100 \mathrm{~g}$ was recorded for 
protein content. This content was higher than the $13.5 \mathrm{~g} / 100 \mathrm{~g}$ recorded for freeze-dried bioflocs from the shrimp waste source obtained in the present study. Although a similar biofloc source (L. vannamei), drying method (freeze-dryer), carbon source (molasses), and $\mathrm{C} / \mathrm{N}$ ratio (15:1) were used in the present study, other factors, such as the density and particle size of the bioflocs, developing period, stocking density, and environmental conditions, were found to affect the nutritional composition of the bioflocs $[8,13,15-17,33,35]$. This is supported by Ekasari et al. [38], who mentioned that the percentage of protein can be influenced by the floc size, where a particular biofloc size of 48-100 $\mu \mathrm{m}$ and >100 $\mu \mathrm{m}$ showed higher protein content than $<48 \mu \mathrm{m}$. From this point of view, the mesh sizes of $20 \mu \mathrm{m}, 30 \mu \mathrm{m}$, and $40 \mu \mathrm{m}$ used in the present study might have caused an abundance of small organisms in the bioflocs $(<48 \mu \mathrm{m})$ rather than larger organisms $(>48 \mu \mathrm{m})$ and so might have influenced the protein content of the bioflocs in the four experimental treatment groups. In the present study, the freeze-dryer positively affected the protein content in bioflocs from both sources (shrimp waste and tilapia waste). This positive effect could be due to the advantage of the freeze-drying method, which is widely used to dry sensitive products such as microbial samples without diminishing their protein content [27].

Lipids typically make up about 7-15 g/100 g of a fish diet to supply essential fatty acids and serve as transporters for fat-soluble vitamins [57]. The crude lipid content of the bioflocs found in this study was low, ranging from 0.35-0.92 g/100 g. Nevertheless, the lipid values were in line with previous studies reported by Emerenciano et al. [12,14], Anand et al. [37], Himaja [41], and Durigon et al. [43]. In general, the lipid content in biofloc is usually low, with concentrations ranging from below 0.1 to $2.5 \mathrm{~g} / 100 \mathrm{~g}$ [20,22,30,36,58,59].

Drying in a hot air oven at $45^{\circ} \mathrm{C}$ provided a lipid content ranging from $0.5-3.5 \mathrm{~g} / 100 \mathrm{~g}$ in bioflocs [37,40,41]. Furthermore, using oven drying at $55^{\circ} \mathrm{C}$ for $72 \mathrm{~h}$ resulted in a crude lipid content of $1.22 \mathrm{~g} / 100 \mathrm{~g}$ in tilapia waste bioflocs [43]. Drying bioflocs in an oven at a high temperature $\left(102{ }^{\circ} \mathrm{C}\right)$ resulted in a lipid ratio of $0.47 \mathrm{~g} / 100 \mathrm{~g}$ [12] and Kuhn et al. [22] found a low lipid proportion of 0.42 in dried bioflocs, using air drying in a greenhouse. In contrast, Lee et al. [18] used a freeze-drying method to dry bioflocs collected from a shrimp tank and achieved $2.30 \mathrm{~g} / 100 \mathrm{~g}$ of lipid content. Accordingly, the drying methods might affect the lipid levels of bioflocs in the present study.

Table 1 shows very high significant differences in lipid contents between the oven-dried bioflocs and the freeze-dried bioflocs $(p<0.05)$, and the highest value $(0.92 \pm 0.01 \mathrm{~g} / 100 \mathrm{~g})$ was recorded for the ODSBF samples where the bioflocs were dried in the oven at $40{ }^{\circ} \mathrm{C}$. However, when a similar drying temperature $\left(40{ }^{\circ} \mathrm{C}\right)$ was used by Khatoon et al. [42] to dry waste bioflocs harvested from a shrimp waste pond, a value of $4.2 \pm 0.1$ was recorded for the lipid content of the bioflocs. However, the higher lipid content might be due to the different types of biofloc, the aquaculture conditions, and the abundance of the organic matter in that pond $[8,10,13,15-18,33-36]$.

The ash content of the bioflocs in the present study was high, ranging from 42.45-61.01 $\mathrm{g} / 100 \mathrm{~g}$ and the values are in agreement with previous studies $[18,36,40,60-62]$. Tacon et al. [63] reported that a high ash content in bioflocs may be related to the abundance of acid-insoluble oxides and mixed silicates. In view of the fact that the term biofloc refers to a collection of microbial communities, such as diatoms [17], microalgae (diatoms) increase aquaculture production, especially in shrimp ponds [9]. Moreover, the cell walls of these microalgae contain silicate, which is an important mineral for building shrimp exoskeletons [64]. In some studies, diatoms were added to maintain water quality and generate heterotrophic bacteria [12].

We found that the ash content in bioflocs from shrimp waste is significantly higher than that in bioflocs from tilapia waste $(p<0.05)$. Consequently, the source of biofloc had a significant effect on the ash content, where the highest ash values $(61.01 \pm 0.29$ and $60.63 \pm 0.29 \mathrm{~g} / 100 \mathrm{~g}$ ) were recorded for shrimp waste bioflocs. The high content of ash in bioflocs from shrimp waste may be due to the high salt concentration in the shrimp tanks $[60,65]$. On the other hand, no significant effect was found of the drying methods on ash content of bioflocs in the present study $(p>0.05)$. Overall, bioflocs from the tilapia 
waste showed lower ash content than bioflocs from the shrimp waste. Thus, tilapia waste positively affected the ash content of the bioflocs. No significant effect was documented for the impact of drying methods on the ash contents of bioflocs from either waste source.

In this study, we observed that the crude fiber content of tilapia waste bioflocs $(16.61 \pm 0.29-17.11 \pm 0.29 \mathrm{~g} / 100 \mathrm{~g})$ was higher compared to shrimp waste bioflocs $(7.43 \pm 0.29-7.74 \pm 0.29 \mathrm{~g} / 100 \mathrm{~g})$, where the FDSBF samples showed the lowest fiber content $(p<0.05)$. A similar value of $16.6 \mathrm{~g} / 100 \mathrm{~g}$ was found for the crude fiber content of dried biofloc collected from food-processing industry waste [22]. Moreover, Kuhn et al. [20] recorded a crude fiber content of $12.6 \mathrm{~g} / 100 \mathrm{~g}$ for shrimp waste biofloc, which falls in the mid-range of the values recorded in the present study. The drying methods did not significantly affect the fiber contents of bioflocs from either shrimp or tilapia waste sources $(p>0.05)$. The waste source used to derive the biofloc significantly affected the fiber content $(p<0.05)$, where the shrimp waste bioflocs showed the lowest fiber content.

In the present study, the high fiber content of tilapia waste bioflocs may be due to the higher level of feces in tilapia tanks compared with shrimp tanks. Tilapia exhibit a feeding activity that is almost constant during daylight hours, and always move and consume organic matter in situ in the water column $[66,67]$. Unlike tilapia, shrimp are bottom feeders and they move slowly, usually staying on the floor of the tank and mostly hiding, and there are several factors that influence the ingestion rate of feed in shrimp $[68,69]$. Thus, shrimp produce less feces as a result of their characteristics.

The nitrogen free extract (NFE) results in the present study ranged from $16.45 \pm 0.17$ to $18.59 \pm 0.10 \mathrm{~g} / 100 \mathrm{~g}$, higher in shrimp waste bioflocs than in tilapia waste bioflocs, where the samples from the ODSBF treatment group had the highest value of $18.59 \mathrm{~g} / 100 \mathrm{~g}$ (Table 1). Carbohydrate levels (20-45 g/100 g) that are typically added to fish diets do not cover the carbohydrate requirements of aquaculture animals. However, Kuhn et al. [22] recorded a slightly higher carbohydrate level $(19.0 \mathrm{~g} / 100 \mathrm{~g})$ in dried biofloc collected from a food-processing, suspended-growth biological reactor. Anand et al. [37] and Emerenciano et al. [12] found total NFE contents of $29.24 \mathrm{~g} / 100 \mathrm{~g}$ and $29.40 \mathrm{~g} / 100 \mathrm{~g}$, respectively in bioflocs. Table 1 shows that the significant differences $(p<0.05)$ between the means of the shrimp waste and tilapia waste bioflocs indicate that the sources of bioflocs and the methods of drying significantly affected the total NFE content $(p<0.05)$, where the ODSBF samples from the shrimp waste showed the highest level of total NFE $(18.59 \pm 0.10 \mathrm{~g} /$ $100 \mathrm{~g})$. Although there is no specific dietary requirement for carbohydrates, they are still included in diets because of their low cost and their function as an energy source (in addition to lipids) [70]. If adequate percentages of carbohydrates and lipids are present in the diet, the protein can then be used efficiently for growth. If not, expensive protein may be used as a source of energy to cover metabolic activities and other life activities rather than for growth $[57,66]$.

The gross energy of bioflocs from the present study ranged from 0.99 to $1.94 \mathrm{Kcal} \mathrm{g}^{-1}$ (Table 1). The range of energy was in agreement with the gross energy of $1.96 \mathrm{Kcal} \mathrm{g}^{-1}$ in biofloc harvested from a $12 \mathrm{~m}^{3}$ outdoor pilot reactor treating wastewater from a pikeperch culture by Hende et al. [62] and $1.86 \mathrm{Kcal} \mathrm{g}^{-1}$ in biofloc collected from a shrimp pond by Parbu et al. [36]. However, in a study by Emerenciano et al. [12], the gross energy of shrimp biofloc dried in an oven at $102{ }^{\circ} \mathrm{C}$ (until stable weight) was higher $\left(2.916 \mathrm{Kcal} \mathrm{g}^{-1}\right)$ than in our findings, where the maximum level of energy was found to be $1.94 \mathrm{Kcal} \mathrm{g}^{-1}$ in the tilapia bioflocs dried in the oven at $40{ }^{\circ} \mathrm{C}$ for $72 \mathrm{~h}$. Furthermore, using bioflocs developed in three indoor tanks without any stock of cultured organisms showed a gross energy content of $3 \mathrm{Kcal} \mathrm{g}^{-1}$ ([37,55]. Statistically, the sources of bioflocs had a significant effect on the gross energy content of the bioflocs $(p<0.05)$, while the methods of drying only had significant effect on bioflocs from the tilapia waste.

AAs play an essential role in the metabolic functions in the body that are important for maintenance, growth, immunity, and reproduction in various fish $[54,57,71]$. We observed that both the EAAs and NEAAs of the four experimental biofloc sample groups in general ranged from $0.204 \pm 0.01 \mathrm{~g} / 100 \mathrm{~g}$ for methionine to $2.317 \pm 0.03 \mathrm{~g} / 100 \mathrm{~g}$ for glutamic, 
where the FDTBF samples showed the highest total of AAs followed by the ODTBF samples, while the FDSBF and ODSBF samples were lacking in most EAAs. However, it can be seen that there are acceptable NEAA values in the samples from each group (Table 2). A similar investigation of nine EAAs was carried out in dried biofloc from shrimp tanks by Lee et al. [18] that recorded 0.41, 1.17, 1.31, 1.51, 0.36, 1.11, 1.02, 1.81, and $1.16 \%$ for histidine, arginine, threonine, valine, methionine, lysine, isoleucine, leucine, and phenylalanine, respectively. Even though those values are slightly higher for most of the EAAs, the histidine levels in the present study were clearly higher in the bioflocs from the tilapia tanks, while the methionine level was the same in the FDTBF samples. Furthermore, both the EAAs and NEAAs of dried biofloc collected from food processing suspended growth biological reactors were studied by Kuhn et al. [22], and their results were also higher for most of the AAs than observed in our results. However, a concentration of $0.93 \mathrm{~g} / 100 \mathrm{~g}$ of histidine was lower than in our study $(2.17$ and $1.88 \mathrm{~g} / 100 \mathrm{~g}$ for the FDTB and ODTBF samples, respectively), while concentrations of $1.35 \mathrm{~g} / 100 \mathrm{~g}$ for serine and $1.27 \mathrm{~g} / 100 \mathrm{~g}$ for proline were in agreement with the relevant concentrations in the present study. The total AAs in the present study reflect the protein concentrations, where $20.24 \mathrm{~g} / 100 \mathrm{~g}$ of AAs led to the highest protein level of $24 \mathrm{~g} / 100 \mathrm{~g}$ for the FDTBF samples. In Table 2, the EAAs in the FDTBF samples recorded a percentage of $52.29 \%$ of the total of AAs, followed by $51.14 \%$ for the ODTBF samples. The average EAAs percentage in the FDSBF and ODSBF samples was $43 \%$. In general, tilapia bioflocs had higher concentrations of AAs. Thus, bioflocs from tilapia tanks can be considered the most convenient source for bioflocs in terms of AAs. In addition, the freeze-drying method effectively maintained the concentrations of the AAs in the bioflocs.

The functional effects of AAs are not necessarily reflected by their concentrations. For example, although the concentrations of tryptophan are much lower than the concentrations of valine in all cell types, tryptophan has a more versatile role than valine in the body [72]. Additionally, EAAs and NEEAs both promote the growth performance and health of aquatic animals. In other words, both EAAs and NEAAs should be taken into consideration in the formulation of balanced diets to meet the concept of "ideal proteins" and enhance the growth performance in fish as well as the optimization of immune and reproductive functions in all species [71,72].

As a matter of fact, dietary supplementation with specific AAs may provide many benefits for the aquaculture sector, such as increasing the nutritional value of aqua feeds, improving growth performance, suppressing aggressive behaviors, increasing survival rates, improving the efficiency of spawning, optimizing flesh quality, and enhancing immunity and tolerance to extreme environmental conditions [71]. Feedstuffs prepared with plant, bacterial, or yeast proteins are typically poor in methionine and lysine, and these AAs must be supplemented in diets when the sources of proteins are used to replace fishmeal [57]. From Table 2, it can be seen that for the two biofloc sources, the AAs of the shrimp waste bioflocs were significantly different from the AAs of the tilapia waste bioflocs, and they were found to be lacking in AAs $(p<0.05)$. However, the tilapia waste bioflocs mainly lacked methionine, glycine, and hydroxyproline, and, to a lesser degree, tyrosine, whereas the shrimp waste bioflocs lacked most of the EAAs (including methionine) and were relatively lacking in tyrosine, which is an NEAA. In this respect, biofloc meal supplemented with limiting AAs could hold great promise for the development of balanced fish feeds to enhance the efficiency and profitability of global aquaculture production. For instance, a diet with $20 \%$ dried biofloc and $0.3 \%$ tryptophan as a dietary supplement can improve the growth performance of tilapia [73]. Thus, knowledge of the limiting AAs in protein is very important to improve the nutritional quality of diets by supplementation with the required AAs $[47,71,73]$.

Minerals are necessary in the diet for normal metabolic body functions. $\mathrm{Ca}, \mathrm{P}, \mathrm{K}, \mathrm{Mg}$, $\mathrm{Fe}, \mathrm{Cu}, \mathrm{Mn}, \mathrm{Zn}, \mathrm{I}$, and Se are considered as essential minerals for fish, while $\mathrm{Ca}, \mathrm{Cu}, \mathrm{Mg}, \mathrm{P}$, $\mathrm{K}$, Se, and $\mathrm{Zn}$ have been recommended for inclusion in crustacean feeds [74]. The essential mineral requirements for certain fish species have been established by many studies in the 
past two decades: concentrations of $3.4 \mathrm{mg} \mathrm{g}^{-1} \mathrm{Ca}, 9 \mathrm{mg} \mathrm{g}^{-1} \mathrm{P}, 0.6 \mathrm{mg} \mathrm{g}^{-1} \mathrm{Mg}, 3.5 \mathrm{mg} \mathrm{kg}^{-1}$ $\mathrm{Cu}$, and $20 \mathrm{mg} \mathrm{kg}^{-1} \mathrm{Zn}$ are required in tilapia diets, while concentrations of $30 \mathrm{mg} / \mathrm{kg} \mathrm{Fe}$, $0.25 \mathrm{mg} \mathrm{kg}^{-1} \mathrm{Se}$, and $1.1 \mu \mathrm{g} \mathrm{kg}{ }^{-1} \mathrm{I}$ are required in catfish diets, and $8 \mathrm{mg} \mathrm{g}^{-1} \mathrm{~K}$ is required for salmon [75]. However, Kuhn et al. [20,22] found that major mineral concentrations in biofloc ranged from 12.9 to $13.7,4.1$ to $18.1,3.6$ to 7.5 , and 12.7 to $15.5 \mathrm{mg} \mathrm{g}^{-1}$ for $\mathrm{P}, \mathrm{Mg}$, $\mathrm{K}$, and $\mathrm{Na}$, respectively. These concentrations were slightly higher than the range of our values. However, the concentration of Ca (10.7-12.8 $\left.\mathrm{mg} \mathrm{g}^{-1}\right)$ was lower than that in our study (21.85-69.74 $\mathrm{mg} \mathrm{g}^{-1}$ ) (Table 3). On the other hand, concentrations of trace minerals, such as Mn (180.7 mg kg $\left.{ }^{-1}\right)$ and Fe (146.9 $\left.\mathrm{mg} \mathrm{kg}^{-1}\right)$, recorded by Lee et al. [18] in dried biofloc were found to fall within the concentration range for minerals in the present study (Table 3). Furthermore, the concentration of $\mathrm{Zn}$ in the present study was in agreement with that found by Kuhn et al. [20]. Based on the findings of the previous studies, dried biofloc (with comparable mineral concentrations) can successfully be used as a supplement or replacement ingredient in shrimp diets [18,20,22]. Generally, shrimp waste bioflocs seem to be rich in minerals, and the oven-drying method did not diminish the mineral content of the bioflocs in the present study.

In the dried bioflocs studies, several techniques have been used to collect microbial flocs from culture water such as Imhoff cone [51], plankton nets with different mesh size [31,49,50], nylon filter bag with different pore size [37], and centrifuge [65]. Various methods of drying have been executed to create the biofloc meal. Drying under sunlight [36], at room temperature [55,56], in a greenhouse [22], in an oven [12,37,50], or in a freeze-dryer $[18,65]$ are examples of the methods. Even though the differences among techniques in processes and principles, the main aim is how to collect a maximum amount of raw material with minimal time and effort, and dry it in high quality and extended the shelf-life of dried product [25] while storing. In this respect, the major challenge is to dry the raw material in the most efficient way with better dried product quality, less impact on the environment and at the lowest capital and operating costs of the process [76]. In fact, cost aspect is important to assess the benefit of biofloc meal if to be practiced by farmers. Today's increased attention of BFT systems due to their sustainability as an eco-friendly and cost-effective approach for aquaculture sector $[4,10,11,14,15,17,32,51,58]$, coupled with the usage of biofloc meal as an alternative source of animal protein source $[12,20,22,28,36,37,42,55,59,61,62]$, requires more innovation for the collecting processes and drying methods of biofloc with minimal cost and time.

\section{Conclusions}

This study indicates that tilapia waste had a positive effect on the protein (the most expensive ingredient in aquaculture feeding), ash, energy, and AA contents of bioflocs, while shrimp waste had positive effects on the lipid, fiber, total nitrogen free extract (NFE), and mineral contents of the bioflocs in the present study. Freeze-drying showed higher values of protein, ash, fiber, energy, and AA contents, while oven-drying showed higher values of lipid, total nitrogen free extract (NFE), and mineral contents. Therefore, tilapia waste bioflocs are a more convenient source of biofloc meal (in terms of protein, ash, energy, and AAs) than shrimp waste bioflocs. Moreover, freeze-drying is the appropriate drying method for biofloc as it efficiently maintains nutritional quality in terms of protein, ash, fiber, energy, and AAs. It is recommended that future studies test freeze-dried biofloc meal from tilapia waste as a supplement or replacement for feed ingredients in fish diets because of its ability to improve the growth performance of cultured animals.

Author Contributions: Formal analysis, T.B.-A.; writing—original draft preparation, T.B.-A.; writingreview and editing, M.M.H. and S.K.D.; supervision, M.M.H. and S.K.D.; project administration, M.M.H.; funding acquisition, M.M.H. All authors have read and agreed to the published version of the manuscript.

Funding: This research was funded by the UKM research grants (GUP-2020-034 \& DIP-2019-001).

Institutional Review Board Statement: Not applicable. 
Informed Consent Statement: Not applicable.

Data Availability Statement: Data is contained within the article.

Acknowledgments: We would like to thank the Faculty of Science and Tecnology, UKM for providing laboratory services and facilities to conduct this research.

Conflicts of Interest: The authors declare no conflict of interest.

\section{References}

1. Ahmed, N.; Thompson, S. The blue dimensions of aquaculture: A global synthesis. Sci. Total Environ. 2019, 652, 851-861. [CrossRef]

2. Ariffin, F.D.; Halim, A.A.; Hanafiah, M.M.; Awang, N.; Othman, M.S.; Azman, S.A.A.; Bakri, N.S.M. The Effects of African Catfish, Clarias gariepinus Pond Farm's Effluent on Water Quality of Kesang River in Malacca, Malaysia. Appl. Ecol. Environ. Res. 2019, 17, 1531-1545. [CrossRef]

3. Bermann, G.A.; Geist, J. Life cycle assessment of common carp (Cyprinus carpio L.) —A comparison of the environmental impacts of conventional and organic carp aquaculture in Germany. Aquaculture 2019, 501, 404-415. [CrossRef]

4. Hanafiah, M.M.; Leuven, R.S.E.W.; Sommerwerk, N.; Tockner, K.; Huijbregts, M.A.J. Including the Introduction of Exotic Species in Life Cycle Impact Assessment: The Case of Inland Shipping. Environ. Sci. Technol. 2013, 47, 13934-13940. [CrossRef]

5. Ashraf, M.A.; Hanafiah, M.M. Recent advances in assessment on clear water, soil and air. Environ. Sci. Pollut. Res. 2017, 24, 22753-22754. [CrossRef]

6. Ashraf, M.A.; Hanafiah, M.M. Sustaining life on earth system through clean air, pure water, and fertile soil. Environ. Sci. Pollut. Res. 2019, 26, 13679-13680. [CrossRef] [PubMed]

7. Hanafiah, M.M.; Mohamad, N.H.S.M.; Aziz, N.I.H.A. Salvinia molesta dan Pistia stratiotes Sebagai Agen Fitoremediasi Dalam Rawatan Air Sisa Kumbahan. Sains Malays. 2018, 47, 1625-1634. [CrossRef]

8. Mahanand, S.S.; Pandey, P.K. Application of biofloc technology for sustainable aquaculture development. In Advances in Fish Research; Mohanty, B.P., Ed.; Narendra Publishing House: Delhi, India, 2019; Volume VII, pp. 263-274.

9. Nizam, N.U.M.; Hanafiah, M.M.; Noor, I.M.; Karim, H.I.A. Efficiency of Five Selected Aquatic Plants in Phytoremediation of Aquaculture Wastewater. Appl. Sci. 2020, 10, 2712. [CrossRef]

10. Dauda, A.B. Biofloc technology: A review on the microbial interactions, operational parameters and implications to disease and health management of cultured aquatic animals. Rev. Aquac. 2020, 12, 1193-1210. [CrossRef]

11. Bossier, P.; Ekasari, J. Biofloc technology application in aquaculture to support sustainable development goals. Microb. Biotechnol. 2017, 10, 1012-1016. [CrossRef]

12. Emerenciano, M.; Ballester, E.L.C.; Cavalli, R.O.; Wasielesky Jr, W. Biofloc technology application as a food source in a limited water exchange nursery system for pink shrimp Farfantepenaeus brasiliensis (Latreille, 1817). Aquac. Res. 2012, 43, $447-457$. [CrossRef]

13. Avnimelech, Y. Feeding with microbial flocs by tilapia in minimal discharge bio-flocs technology ponds. Aquaculture 2007, 264, 140-147. [CrossRef]

14. Emerenciano, M.; Gaxiola, G.; Cuzon, G. Biofloc technology (BFT): A review for aquaculture application and animal food industry. In Biomass Now-Cultivation and Utilization; Darko, M., Ed.; InTech, Queen's University: Kingston, ON, Canada, 2013; pp. 301-328. [CrossRef]

15. Ogello, E.O.; Musa, S.M.; Aura, C.M.; Abwao, J.O.; Munguti, J.M. An appraisal of the feasibility of tilapia production in ponds using biofloc technology: A review. Int. J. Aquat. Sci. 2014, 5, 21-39. Available online: http://www.journal-aquaticscience.com/ article_73489.html (accessed on 27 January 2021).

16. Serra, F.P.; Gaona, C.A.P.; Furtado, P.S.; Poersch, L.H.; Wasielesky, W., Jr. Use of different carbon sources for the biofloc system adopted during the nursery and grow-out culture of Litopenaeus vannamei. Aquac. Int. 2015, 23, 1325-1339. [CrossRef]

17. Ahmad, I.; Rani, A.M.B.; Verma, A.K.; Maqsood, M. Biofloc technology: An emerging avenue in aquatic animal healthcare and nutrition. Aquac. Int. 2017, 25, 1215-1226. [CrossRef]

18. Lee, C.; Kim, S.; Lim, S.; Lee, K. Supplemental effects of biofloc powder on growth performance, innate immunity, and disease resistance of Pacific white shrimp Litopenaeus vannamei. Fish. Aquat. Sci. 2017, 20, 1-7. [CrossRef]

19. Lara, G.; Hostins, B.; Bezerra, A.; Poersch, L.; Wasielesky Jr, W. The effects of different feeding rates and re-feeding of litopenaeus vannamei in a biofloc culture system. Aquac. Eng. 2017, 77, 20-26. [CrossRef]

20. Kuhn, D.D.; Boardman, G.D.; Lawrence, A.L.; Marsh, L.; Flick, G. Microbial floc meal as a replacement ingredient for fish meal and soybean protein in shrimp feed. Aquaculture 2009, 296, 51-57. [CrossRef]

21. Kuhn, D.D.; Lawrence, A.L.; Boardman, G.D.; Patnaik, S.; Marsh, L.; Flick, G.J. Evaluation of two types of bioflocs derived from biological treatment of fish effluent as feed ingredients for Pacific white shrimp, Litopenaeus vannamei. Aquaculture 2010, 303, 28-33. [CrossRef]

22. Kuhn, D.D.; Lawrence, A.L.; Crockett, J.; Marsh, L.; Taylor, D. Evaluation of bioflocs derived from confectionary food effluent water as a replacement feed ingredient for fishmeal or soy meal for shrimp. Aquaculture 2016, 454, 66-71. [CrossRef] 
23. Phulia, V.; Mandal, B.; Bera, A.; Singh, S.K.; Das, R.; Jamwal, A. Factors controlling biofloc characteristics. World Aquac. 2012, 43, 57-59. Available online: https:/ / www.researchgate.net/publication/320297549_Factors_controlling_biofloc_characteristics (accessed on 27 January 2021).

24. Bong, P.; Malek, M.; Mardi, N.; Hanafiah, M.M. Cradle-to-Gate Water-Related Impacts on Production of Traditional Food Products in Malaysia. Sustainability 2020, 12, 5274. [CrossRef]

25. Hanafiah, M.M.; Huijbregts, M.A.J.; Hendriks, A.J. The Influence of Nutrients and Non- $\mathrm{CO}_{2}$ Greenhouse Gas Emissions on the Ecological Footprint of Products. Sustainability 2010, 2, 963-979. [CrossRef]

26. Hanafiah, M.M.; Ali, M.Y.M.; Aziz, N.I.H.A.; Ashraf, M.A.; Halim, A.A.; Lee, K.E.; Idris, M. Biogas production from goat and chicken manure in Malaysia. Appl. Ecol. Environ. Res. 2017, 15, 529-535. [CrossRef]

27. Berk, Z. Freeze drying (lyophilization) and freeze concentration. In Food Process Engineering and Technology, 3rd ed.; Berk, Z., Ed.; Academic Press: London, UK; Elsevier Inc.: London, UK, 2018; pp. 567-581. [CrossRef]

28. Becerril-Cortés, D.; Monroy-Dosta, M.C.; Coelho-Emerenciano, M.G.; Castro-Mejía, G.; Cienfuegos-Martínez, K.; Lara-Andrade, R. Nutritional importance for aquaculture and ecological function of microorganisms that make up Biofloc, a review. Int. J. Aquat. Sci. 2017, 8, 69-77. Available online: http://www.journal-aquaticscience.com/article_70741_513b984749c03250942f865e5eb86f6a.pdf (accessed on 12 February 2021).

29. Hargreaves, J.A. Biofloc Production Systems for Aquaculture; No. 4503; Southern Regional Aquaculture Center (SRAC): Stoneville, NC, USA, 2013; pp. 1-11. Available online: https://www.academia.edu/22867188/Biofloc_Production_Systems_for_ Aquaculture_Southern_regional_aquaculture_center (accessed on 27 January 2021).

30. Azim, M.E.; Little, D.C. The biofloc technology (BFT) in indoor tanks: Water quality, biofloc composition, and growth and welfare of Nile tilapia (Oreochromis niloticus). Aquaculture 2008, 283, 29-35. [CrossRef]

31. Xu, W.; Pan, L. Effects of bioflocs on growth performance, digestive enzyme activity and body composition of juvenile Litopenaeus vannamei in zero-water exchange tanks manipulating C/N ratio in feed. Aquaculture 2012, 356-357, 147-152. [CrossRef]

32. Luo, G.; Gao, Q.; Wang, C.; Liu, W.; Sun, D.; Li, L.; Tan, H. Growth, digestive activity, welfare, and partial cost-effectiveness of genetically improved farmed tilapia (Oreochromis niloticus) cultured in a recirculating aquaculture system and an indoor biofloc system. Aquaculture 2014, 422, 1-7. [CrossRef]

33. Crab, R.; Chielens, B.; Wille, M.; Bossier, P.; Verstraete, W. The effect of different carbon sources on the nutritional value of bioflocs, a feed for Macrobrachium rosenbergii postlarvae. Aquac. Res. 2010, 41, 559-567. [CrossRef]

34. Wei, Y.; Liao, S.A.; Wang, A.L. The effect of different carbon sources on the nutritional composition, microbial community and structure of bioflocs. Aquaculture 2016, 465, 88-93. [CrossRef]

35. Becerril-Cortés, D.; Monroy-Dosta, M.D.C.; Emerenciano, M.G.C.; Castro-Mejía, G.; Bermúdez, B.S.B.; Correa, G.V. Effect on nutritional composition of produced bioflocs with different carbon sources (Molasses, coffee waste and rice bran) in Biofloc system. Int. J. Fish. Aquat. Stud. 2018, 6, 541-547. Available online: http://www.fisheriesjournal.com/archives/2018/vol6issue2 /PartG/6-2-30-391.pdf (accessed on 12 February 2021).

36. Prabu, E.; Rajagopalsamy, C.B.T.; Ahilan, B.; Jeevagan, I.J.M.A.; Renuhadevi, M. Effect of dietary supplementation of biofloc meal on growth and survival of GIFT tilapia. Indian J. Fish. 2018, 65, 65-70. [CrossRef]

37. Anand, P.S.S.; Kohli, M.P.S.; Kumar, S.; Sundaray, J.K.; Roy, S.D.; Venkateshwarlu, G.; Sinha, A.; Pailan, G.H. Effect of dietary supplementation of biofloc on growth performance and digestive enzyme activities in Penaeus monodon. Aquaculture 2014, 418-419, 108-115. [CrossRef]

38. Ekasari, J.; Angela, D.; HadiWaluyo, S.; Bachtiar, T.; Surawidjaja, E.H.; Bossier, P.; Schryver, P.D. The size of biofloc determines the nutritional composition and the nitrogen recovery by aquaculture animals. Aquaculture 2014, 226, 105-111. [CrossRef]

39. Caldini, N.N.; Cavalcante, D.H.; Filho, P.R.N.R.; Sá, M.V.C. Feeding Nile tilapia with artificial diets and dried bioflocs biomass. Anim. Sci. Mar. 2015, 37, 335-341. [CrossRef]

40. Neto, H.S.; Santaella, S.T.; Nunes, A.J.P. Bioavailability of crude protein and lipid from biofloc meals produced in an activated sludge system for white shrimp, Litopenaeus vannamei. Rev. Bras. Zootec. 2015, 44, 269-275. [CrossRef]

41. Himaja, P.H.; Rajagopalasamy, C.B.; Ahilan, B. Performance of outdoor biofloc meal in the diet of Catla catla, (Hamilton, 1822). The bioscan. Int. Q. J. Life Sci. 2016, 11, 2257-2264. Available online: https://www.semanticscholar.org/paper/PERFORMANCE-OFOUTDOOR-BIOFLOC-MEAL-IN-THE-DIET-OF-Himaja-Rajagopalasamy/8f24714981ab736d94d3ad08df39cd2df0545767 (accessed on 27 January 2021).

42. Khatoon, H.; Banerjee, S.; Yuan, G.T.G.; Haris, N.; Ikhwanuddin, M.; Ambak, M.A.; Endut, A. Biofloc as a potential natural feed for shrimp postlarvae. Int. Biodeterior. Biodegrad. 2016, 113, 304-309. [CrossRef]

43. Durigon, E.G.; Lazzari, R.; Uczay, J.; Lopes, D.L.A.; Jeronimo, G.T.; Sgnaulin, T.; Emerenciano, M.G.C. Biofloc technology (BFT): Adjusting the levels of digestible protein and digestible energy in diets of Nile tilapia juveniles raised in brackish water. Aquac. Fish. 2020, 5, 42-51. [CrossRef]

44. Lobato, O.S.C.; Ribeiro, F.A.S.; Miranda-Baeza, A.; Emerenciano, M.G.C. Production performance of Litopenaeus vannamei (Boone, 1931) fed with different dietary levels of tilapia processing waste silage reared in biofloc system using two carbon sources. Aquaculture 2019, 501, 515-518. [CrossRef]

45. A.O.A.C. Official Methods of Analysis, 20th ed.; D. C. Association of Official Analytical Chemists: Washington, DC, USA, 2016; 3172p. 
46. Das, S.K.; Ghaffar, M.A.G.; Bakar, Y.; Brito, M.F.G.; Mastura, S.S.A.; Temple, S.E. X-radiographic observation of food passage, and nutrient absorption along the alimentary tract of archer fish, Toxotes jaculatrix. Bull. Mar. Sci. 2014, 90, 903-919. [CrossRef]

47. Nollet, L.M.L. Amino acids. In Handbook of Food Analysis, 2nd ed.; Nollet, L.M.L., Ed.; Marcel Dekker, Inc.: New York, NY, USA, 2004; pp. 83-123.

48. Ali, M.Y.; Hanafiah, M.M.; Khan, M.F.; Latif, M.T. Quantitative source apportionment and human toxicity of indoor trace metals at university buildings. Build. Environ. 2017, 121, 238-246. [CrossRef]

49. Long, L.; Yang, J.; Li, Y.; Guan, C.; Wu, F. Effect of biofloc technology on growth, digestive enzyme activity, hematology, and immune response of genetically improved farmed tilapia (Oreochromis niloticus). Aquaculture 2015, 448, 135-141. [CrossRef]

50. Rajkumar, M.; Pandey, P.K.; Aravind, R.; Vennila, A.; Bharti, V.; Purushothaman, C.S. Effect of different biofloc system on water quality, biofloc composition and growth performance in Litopenaeus vannamei (Boone, 1931). Aquac. Res. 2015, 47, 1-13. [CrossRef]

51. Cang, P.; Zhang, M.; Qiao, G.; Sun, Q.; Xu, D.; Li, Q.; Yuan, X.; Liu, W. Analysis of Growth, Nutrition and Economic Profitability of Gibel Carp (Carassius auratus gibelio $q \times$ C. carpio $\sigma^{7}$ ) Cultured in Zero-water Exchange System. Pak. J. Zool. 2019, 51, 619-630. [CrossRef]

52. Li, J.; Li, J.; Li, W.; Sun, Y.; Liu, X.; Liu, M.; Cheng, Y. Juvenile Procambarus clarkii farmed using biofloc technology or commercial feed in zero-water exchange indoor tanks: A comparison of growth performance, enzyme activity and proximate composition. Aquac. Res. 2019, 50, 1834-1843. [CrossRef]

53. Promthale, P.; Pongtippatee, B.; Withyachumnarnkul, B.; Wongprasert, K. Bioflocs substituted fishmeal feed stimulates immune response and protects shrimp from Vibrio parahaemolyticus infection. Fish. Shellfish Immunol. 2019, 93, 1067-1075. [CrossRef]

54. FAO. The Nutrition and Feeding of Farmed Fish and Shrimp-A Training Manual; 1. The Essential Nutrients. Government Cooperative Programme; Tacon, A.G.J., Ed.; FAO/UNDP: Roma, Italy, 1987. Available online: http://www.fao.org/3/ab470e/AB470E00.htm\# TOC (accessed on 27 January 2021).

55. Chen, J.; Ren, Y.; Wang, G.; Xia, B.; Li, Y. Dietary supplementation of biofloc influences growth performance, physiological stress, antioxidant status and immune response of juvenile sea cucumber Apostichopus japonicus (Selenka). Fish. Shellfish Immunol. 2018, 72, 143-152. [CrossRef] [PubMed]

56. Harini, C.; Rajagopalasamy, C.B.T.; Kumar, J.S.S.; Santhakumar, R. Role of Biofloc in the Growth and Survival of Blue morph, seudotropheus saulosi. Indian J. Sci. Technol. 2016, 9, 1-7. [CrossRef]

57. Virginia Cooperative Extension. Understanding Fish Nutrition, Feeds and Feeding. Craig, S., Helfrich, L., Eds.; 2017. Available online: https: / /www.pubs.ext.vt.edu/FST /FST-269/FST-269.html (accessed on 27 January 2021).

58. Avnimelech, Y. Biofloc Technology —A Practical Guide Book, 2nd ed.; The World Aquaculture Society: Baton Rouge, LA, USA, 2015; $268 \mathrm{p}$.

59. Bauer, W.; Prentice-Hernandez, C.; Tesser, M.B.; Wasielesky Jr, W.; Poersch, L.H.S. Substitution of fishmeal with microbial floc meal and soy protein concentrate in diets for the pacific white shrimp Litopenaeus vannamei. Aquaculture 2012, 342-343, 112-116. [CrossRef]

60. Maica, P.F.; de Borba, M.R.; Wasielesky Jr, W. Effect of low salinity on microbial floc composition and performance of Litopenaeus vannamei (Boone) juveniles reared in a zero-water-exchange super-intensive system. Aquac. Res. 2012, 43, 361-370. [CrossRef]

61. Hende, S.F.D.; Claessens, L.; De Muylder, E.; Boon, N.; Vervaeren, H. Microbial bacterial flocs originating from aquaculture wastewater treatment as diet ingredient for Litopenaeus vannamei (Boone). Aquac. Res. 2014, 47, 1075-1089. [CrossRef]

62. Magondu, E.W.; Verdegem, M.C.J.; Nyamora, J.; Nyakeya, K. Proximate composition, nutritional properties and attractiveness of Aerobic, Anaerobic and Anoxic bioflocs as a fish feed. Int. J. Fish. Aquat. Stud. 2016, 4, 280-287. Available online: http: / / www.fisheriesjournal.com/archives / ?year=2016\&vol=4\&issue=1\&part=D\&ArticleId=639 (accessed on 27 January 2021).

63. Tacon, A.G.J.; Cody, J.J.; Conquest, L.D.; Divakaran, S.; Forster, I.P.; Decamp, O.E. Effect of culture system on the nutrition and growth performance of Pacific white shrimp Litopenaeus vannamei (Boone) fed different diets. Aquac. Nutr. 2002, 8, 121-137. [CrossRef]

64. Suantika, G.; Situmorang, M.L.; Aditiawati, P.; Astuti, D.I.; Azizah, F.F.; Muhammad, H. Closed aquaculture system: Zero water discharge for shrimp and prawn farming in Indonesia. In Biological Resources of Water; Ray, S., Ed.; IntechOpen: London, UK, 2018; pp. 297-327. [CrossRef]

65. Ju, Z.Y.; Forster, I.; Conquest, L.; Dominy, W. Enhanced growth effects on shrimp (Litopenaeus vannamei) from inclusion of whole shrimp floc fractions to a formulated diet. Aquac. Nutr. 2008, 14, 533-543. [CrossRef]

66. Gatlin, D.M. Principles of Fish Nutrition; No. 5003; Southern Regional Aquaculture Center (SRAC): Stoneville, NC, USA, 2010; pp. 1-8. Available online: https://www.semanticscholar.org/paper/Principles-of-Fish-Nutrition-Gatlin/69de26125fc2ab5c58d3 7d5b5da5f96e23859968\#paper-header (accessed on 27 January 2021).

67. Day, S.B.; Salie, K.; Stander, H.B. A growth comparison among three commercial tilapia species in a biofloc system. Aquacult. Int. 2016, 24, 1309-1322. [CrossRef]

68. Parra-Flores, A.M.; Ponce-Palafox, J.T.; Spanopoulos-Hernández, M.; Martinez-Cardenas, L. Feeding behavior and ingestion rate of juvenile shrimp of the genus Penaeus (Crustacea: Decapoda). Open Access J. Sci. 2019, 3, 111-113. [CrossRef]

69. Prangnell, D.I.; Lupatsch, I.; Treece, G.D.; Samocha, T.M. Shrimp biology. In Sustainable Biofloc Systems for Marine Shrimp; Samocha, T.M., Ed.; Academic Press: London, UK; Elsevier Inc.: London, UK, 2019; pp. 19-27. [CrossRef] 
70. Lall, S.P.; Dumas, A. Nutritional requirements of cultured fish: Formulating nutritionally adequate feeds. In Feed and Feeding Practices in Aquaculture; Davis, D.A., Ed.; Woodhead Publishing Series in Food Science, Technology and Nutrition: Cambridge, UK, 2015; pp. 53-109. [CrossRef]

71. Li, P.; Mai, K.; Trushenski, J.; Wu, G. New developments in fish amino acid nutrition: Towards functional and environmentally oriented aquafeeds. Amino Acids 2009, 37, 43-53. [CrossRef]

72. Wu, G. Functional amino acids in growth, reproduction, and health. Am. Soc. Nutr. Adv. Nutr. 2010, 1, 31-37. [CrossRef]

73. Prabu, E.; Rajagopalsamy, C.B.T.; Ahilan, B.; Jeevagan, I.J.M.A.; Renuhadevi, M. Effect of dietary supplementation of biofloc meal with tryptophan on growth and survival of GIFT Tilapia. Int. J. Curr. Microbiol. App. Sci. 2017, 6, 3426-3434. [CrossRef]

74. Dullah, H.; Malek, M.A.; Hanafiah, M.M. Life cycle assessment of nile tilapia (Oreochromis niloticus) farming in Kenyir Lake, Terengganu. Sustainability 2020, 12, 2268. [CrossRef]

75. Lall, S.P. The minerals. In Fish Nutrition, 3rd ed.; Halver, J.E., Hardy, R.W., Eds.; Academic Press: An Elsevier Science Imprint: Cambridge, MA, USA, 2002; p. 259.

76. Betoret, E.; Calabuig-Jiménez, L.; Barrera, C.; Rosa, M.D. Sustainable drying technologies for the development of functional foods and preservation of bioactive compounds. In Sustainable Drying Technologies; Olvera, J.R., Ed.; IntechOpen: London, UK, 2016; pp. 37-57. [CrossRef] 